\title{
Identification of Student Attitudes toward Physics Learning at Batanghari District High School
}

\author{
Astalini, Dwi Agus Kurniawan*, Rahmat Perdana, Deti Kurniasari \\ Faculty of Teaching and Education, University Jambi, Jambi, Indonesia
}

How to cite this paper: Astalini, Kurniawan, D. A., Perdana, R., \& Kurniasari, D. (2018). Identification of Student Attitudes toward Physics Learning at Batanghari District High School. The Educational Review, USA, 2(9), 475-484. http://dx.doi.org/10.26855/er.2018.09.003

Corresponding author: Dwi Agus Kurniawan, Profesional Lecture, Faculty of Teaching and Education, Jambi University, Jambi, Indonesia.

\begin{abstract}
This study aims to determine students' attitudes toward physics learning at State Senior High School in Batanghari District Method: The type of research used is quantitative design using Survey Research which is corroborated with interview results to support quantitative data. The study involved 926 students of Batanghari State High School. Data used by researchers in the form of questionnaire/questionnaire consisting of 54 items statement using Likert scale 5. Data analysis: for Quantitative data using descriptive statistics. Findings: The results of this study researchers get good results and good enough with the following details: Adoption from Scientific Attitude has a Good result of 56\%, Pleasure in Learning Physics has a result enough 55.5\%, Interest in Spending Physics Learning Time has a result of $57.9 \%$, Interest in Care in the field of Physics has enough results of $46 \%$.
\end{abstract}

\section{Keywords}

Attitude, Scientific Attitude, Enjoyment, Interest , Physics, Career

\section{Introduction}

Education is a very important activity, By Allowing Human Education to Change Behavior and Knowledge to Be Better. As it is known that education is the process of seeking and instilling skills undertaken by students (Wood, 2011). The purpose of education itself is to develop the potential of agar-agar peel to think critically and creatively (Indonesia, 2003). In education consists of several levels one of the high school levels. High school is the level of education required before education to a higher level. In the level of high school education a variety of science that one of the science that is studied is the science of physics. Physics is a science that connects with the behavior and natural phenomena associated with current phenomena or phenomena that occur today (Giancoli, 2014).

Physics lesson is one of Lesson's less favored subjects. Students consider physics as a difficult subject for schooling and it is increasingly difficult to get them to college (Guido, 2013). In the process of student, the behavior is very important. Attitudes that occur during a very important process in human movement (Kaya, 2011). Students who have this view will have different values from students who are more positive during the learning process. Positive attitudes of students in process learning can produce good learning achievement and instead. (Arsaythamby Veloo, 2015) "with students who have positive situations and learning can improve their learning achievement".

The attitude comes from the feelings of people who are reflected in feelings of likes or dislikes. Students who can not learn visually. Learning outcomes and attitudes toward physics. Both negative and positive attitudes in physics learning greatly affect learning outcomes in physics and science, knowing that if students behave negatively to learning will make learning now 
or in the future more difficult (Erdemir, 2009). The lack of positive attitudes of students to Lessons causes problems. Students who have negative attitudes toward physics will reduce their level of confidence and make poor work resulting in information problems to solve physics problems (Olasimbo, 2012). And if students have a negative attitude towards the Lesson of physics then they will also be negative towards physics teacher (Guido, 2013). The positive attitude of students in the eyes of physics lessons will be related to scientific attitudes, physics learning, interest in time, physics, and interested in the field of physics.

Attitude scientific is one of the important aspects of science (Khan, Shah, \& Mahmood Zareen, 2012). Because scientific attitudes can shape students' minds critically. The importance of the scientific attitude that a student must possess is to acquire knowledge in various fields (Kamisah, 2007). The complicated and abstract learning of physics requires students to be scientific. Scientific attitudes can be illustrated by expressions or reactions that show up according to the ethics of science (Farooq, 2012). With students being able to behave scientifically will help to gain good learning outcomes (Fakhrudin, 2010). Students with a high scientific attitude will have the attitude towards physics a positive.

Positive student attitudes toward physics will have a sense of fun when the learning process takes place. The pleasure of students in learning will have a more intensive character in learning (Manasi, 2015). Students who have a great pleasure in learning physics will affect physics results. Good physics results are influenced by the enjoyment of students' science and pleasure giving a predictive effect of value in science learning (Ainley, 2011). Students who are happy in learning physics will have a high curiosity towards physics. High curiosity is influenced by several factors of one of his comfortable classrooms. Rawatee Maharaj-Sharma (2017) "comfortable classrooms can develop student skills and enhance physics learning pleasure".

The pleasure of students in learning physics will affect students interested in increasing the time studying physics and science. Student attitudes toward science learning refer to the feelings of pleasure or interest of participants in learning science (Esther Agunbiade, 2017). Students who consider physics difficult because he is not interested in increasing the time of learning physics. The lack of interest of students in increasing the time of physics learning led to failure in the achievement of physics learning (Visser, 2007). The interest of students in multiplying the study of physics can be seen from the achievements in the field of science and physics. Students who are interested in increasing the time of physics learning will affect the achievements, learning outcomes and careers in physics (Rodger Bybee, 2009). With the more often his students increase the time to learn then the good increasingly also its value or the resulting learning. Therefore, the interest of students in increasing the time of physics learning is needed to achieve good learning outcomes.

The results of physics learning and student attitudes will affect students in the interest of a career in the field of physics. If a student is negative toward physics then the student has no interest in a career in physics. Positive attitudes and interests toward physics will bring future careers into the field of physics will increase (Welch, 2010). Because of the difficulty in physics causes students are not interested in a career in physics. Many students who are physics is boring and for a career in physics is a tough job (Arsaythamby Veloo, 2015). One that affects students to be able to work in the field of physics is interest or interest. Therefore, to be able to increase students in a career in the field of physics to note the interest in which interest greatly affect the achievement of his career and personal life (Arslan, 2015).

Attitude is very important in the process of learning. Because if students have a negative attitude towards the subject of physics then they will also be negative to physics teacher (Guido, 2013). Therefore the teacher must know how the attitude of students that occur in the poses of learning because by knowing the attitude of student teachers can improve the design of learning in the classroom in accordance with the ability that students have. One of the student attitudes that a teacher needs to pay attention to is a scientific attitude. Trumper (2006) "scientific attitude greatly influences the learning process involving student attitudes". Students who have a high scientific attitude will help the process of science and physics improves for the better. This is because the scientific attitude can form students think creatively and critically.

The purpose of this research is to know the student's attitude toward physics learning at his high school at Batanghari High 
School. Indicator attitudes include the adoption of scientific attitudes, interest in learning physics, interest in increasing the time study of physics, and interest in physics career. In this study research questions as follows:

- How to describe students' scientific attitude toward physics learning?

- How to describe students' fun attitude in learning physics?

- How to describe the attitude of student interest in increasing the time study physics?

- How to describe the attitude of student interest in a career in the field of physics?

- What are the obstacles faced to improve students' attitudes in physics learning?

- How is the solution to improve students' attitude in a physics lesson

The findings of this study may contribute to improving students attitudes toward physics learning. This research is very important especially at high school level because attitudes can influence learning outcomes.

\section{Method}

\subsection{Research Design}

This research design is quantitative research using survey research design. Procedures in quantitative research in which investigators administer surveys on samples or entire populations used for personal attributes, opinions, or styles (Creswell, 2012). In this research design is applied because in accordance with the purpose, namely learning about High School Students Attitudes toward the subjects of Physics.

\subsection{Sample Research}

The sample that researchers use comes from 926 students consisting of 5 high schools located in Batanghari District 2017-2018 period in even semester. With the details of each school: 1. SMAN 1 Batanghari as many as 281 students with male students 119 people and female students as much as 162 people, 2. SMAN 5 Batanghari 126 students with male students of 58 people and female students of 68 people, 3. SMAN 6 Batanghari 225 students with male students 87 people and female students 138 people, 4. SMAN 8 Batanghari 141 students with male students as many as 32 people and female students as many as 109 people and SMAN 10 Batanghari as many as 153 students with male students as many as 57 people and female students as many as 96 people. In this research, the researcher uses two sampling techniques, total sampling, and purposive sampling. Where total sampling is used to find quantitative data while purposive sampling is sampling technique based on the criterion from the researcher (Kerlinger, 2014).

\subsection{Instruments and Procedures}

In this study, the researchers used questionnaire instrument where, the questionnaire had 54 statements with 7 indicators. This result was adopted from Rio darmawangsa research with Cronbach alpha reliability test greater than 0.8 with 54 valid statements (Darmawangsa, 2018). In this study, the researchers used 4 indicators using the Likert scale 5 (five) (positive statement Very Not Good has score 1, Not Good has score 2, Neutral has a score of 3, Good to have a score of 4 and Very Good 5. For negative statements Very Not Good has a score of 5, Not Good has a score of 4, Neutral has a score of 3, Good have score 2 and Very Good to have a score 1). Interviews use semi-structured interview types.

\subsection{Data Analysis}

The data in this study uses quantitative data analysis using SPSS program to find descriptive statistics, descriptive statistics is a description or presentation of a large amount of data, in this case, the summary frequency, for example, mode, mean, median, minimum, maximum and standard deviation (Cohen, Manion \& Morrison, 2007). Followed by interviews intended to 
strengthen the results of quantitative data. The steps in the interview can be seen as follows : (1) to calculate frequencies such as ideas, themes, pieces of data and words. (2) pay attention to patterns and themes. (3) try to make good data, using intuition to reach conclusion. (4) is a group set items into categories, types, behavior, and classification? (5) makes a metaphor that uses figurative language and connotative rather than literal and denotative language, animates data, thereby reducing data, making patterns, aligning data, linking data with theory. (6) separate variables to decipher, differentiate and 'unpack' ideas, ie move from drive to integration and obfuscate data. (7) surrendered specifically into the general, carrying a large number of variables under a small number of (frequently) unobserved hypothetical variables. (8) identifies and records relationships between variables. (9) finds an intervening variable: looks for another variable that seems to 'block' calculations for what is expected to be a strong relationship between variables. (10) building logical chain of evidence: noting causality and making conclusions. (11) Creating conceptual/theoretical coherence: moving from metaphor to construct to tories to explain phenomena (Cohen, Manion \& Morrison, 2007).

\section{Results and Discussions}

\subsection{Results}

\section{Adoption of a Scientific Attitude}

In the adoption of this scientific attitude, we can see the results from the questionnaire that has been disseminated, with results like Table 1.

Table 1. Adoption of scientific attitude at State Senior High School Batanghari District.

\begin{tabular}{|c|c|c|c|c|c|c|c|c|c|}
\hline \multicolumn{3}{|c|}{ Classification } & \multirow{2}{*}{$\begin{array}{l}\text { Standard } \\
\text { deviation }\end{array}$} & \multirow[t]{2}{*}{ Mean } & \multirow[t]{2}{*}{ Mode } & \multirow[t]{2}{*}{ Median } & \multirow[t]{2}{*}{ Min } & \multirow[t]{2}{*}{ Max } & \multirow[t]{2}{*}{$\%$} \\
\hline Range & Attitude & Total & & & & & & & \\
\hline $7-12.5$ & $\begin{array}{ll}\text { Very } & \text { Not } \\
\text { Good } & \end{array}$ & 1 & & & & & & & $0.1 \%$ \\
\hline $12.6-18.1$ & Not Good & 5 & & & & & & & $0.5 \%$ \\
\hline $18.2-23.7$ & Self & 338 & 3.32 & 25.6 & 27 & 26 & 7 & 35 & $36.5 \%$ \\
\hline $23.8-29.4$ & Good & 519 & & & & & & & $56 \%$ \\
\hline $29.5-35$ & Very Good & 63 & & & & & & & $6.8 \%$ \\
\hline & TAL & 926 & & & & & & & $100 \%$ \\
\hline
\end{tabular}

In the Table 1 obtained from 926 respondents who come from high school education level has filled in a questionnaire and processed using SPSS program. Then the result is as follows: Mean 25.6, Mode 27, Median 26, Minimum Score 7, Maximum Score 35 and Standard Deviation of 3.32. above obtained from the questionnaire data that has been processed in the SPSS program, which is obtained from 926 respondents from secondary education level above that is more focused on the adoption of the scientific attitude. The result is that the dominant respondents chose a good category, which is 56\% totaling 519 of 926 students, then good enough at 36.5\% totaling 338 of 926 students, very good $6.8 \%$ totaling 63 of 926 students, not good at $0.5 \%$ totaling 5 out of 926 students and very not good as many as $0.1 \%$ totaling 1 of 926 people.

\section{Pleasure in Learning Physics}

The results of questionnaires that have been processed about the Pleasure in Learning Physics can be seen in Table 2.

In the Table 2 obtained from 926 respondents from high school education level has filled in the questionnaire and processed using SPSS program. Then the result is as follows: Mean 32.3, Mode 31, Median 32, Minimum Score 10, Maximum Score 50 and Standard Deviation of 6.47. From the result of Table 2 above, it was processed using SPSS program, which was obtained from 926 respondents from high school education level, where more emphasized on the indicator of Pleasure in Learning Physics, where the most dominant chose was good enough as much as 55.5\% with a total of 514 of 926 students, then a good $22.7 \%$ with a total of 210 of 926 students and very good at $2.7 \%$ with a total of 25 of 926 stu- 
dents, for the Not Good category 16, 8\% with a total of 156 of 926 students and Very Not Good of 2.3\% with a total of 21 of 926 students.

Table 2. Pleasure in physics learning at State Senior High School Batanghari District.

\begin{tabular}{|c|c|c|c|c|c|c|c|c|c|}
\hline \multicolumn{3}{|c|}{ Classificaction } & \multirow{2}{*}{$\begin{array}{l}\text { Standard } \\
\text { deviation }\end{array}$} & \multirow[t]{2}{*}{ Mean } & \multirow[t]{2}{*}{ Mode } & \multirow[t]{2}{*}{ Median } & \multirow[t]{2}{*}{ Min } & \multirow[t]{2}{*}{ Max } & \multirow[t]{2}{*}{$\%$} \\
\hline Range & Attitude & Total & & & & & & & \\
\hline $10-17$ & $\begin{array}{ll}\text { Very } & \text { Not } \\
\text { Good } & \end{array}$ & 21 & & & & & & & $2.3 \%$ \\
\hline $18-25$ & Not Good & 156 & & & & & & & $16.8 \%$ \\
\hline $26-33$ & Self & 514 & 6.47 & 32.3 & 31 & 32 & 10 & 50 & $55.5 \%$ \\
\hline $34-41$ & Good & 210 & & & & & & & $22.7 \%$ \\
\hline $42-50$ & Very Good & 25 & & & & & & & $2.7 \%$ \\
\hline & TAL & 926 & & & & & & & $100 \%$ \\
\hline
\end{tabular}

\section{Interest Increases Physical Learning Time}

The results of the questionnaire that has been processed about the Interest of Increasing Physics Learning Time can be seen in Table 3.

Table 3. Interest increases physics study time in State Senior High School Batanghari District.

\begin{tabular}{|c|c|c|c|c|c|c|c|c|c|}
\hline \multicolumn{3}{|c|}{ Classification } & \multirow{2}{*}{$\begin{array}{l}\text { Standard } \\
\text { deviation }\end{array}$} & \multirow[t]{2}{*}{ Mean } & \multirow[t]{2}{*}{ Mode } & \multirow[t]{2}{*}{ Median } & \multirow[t]{2}{*}{ Min } & \multirow[t]{2}{*}{ Max } & \multirow[t]{2}{*}{$\%$} \\
\hline Range & Attitude & Total & & & & & & & \\
\hline $8-14.3$ & $\begin{array}{ll}\text { Very } & \text { Not } \\
\text { Good } & \end{array}$ & 18 & & & & & & & $1.9 \%$ \\
\hline $14.4-20.7$ & Not Good & 132 & & & & & & & $14.3 \%$ \\
\hline $20.8-27.1$ & Self & 536 & 4.81 & 24.72 & 25 & 25 & 8 & 39 & $57.9 \%$ \\
\hline $27.2-33.5$ & Good & 204 & & & & & & & $22 \%$ \\
\hline $33.6-40$ & Very Good & 36 & & & & & & & $3.9 \%$ \\
\hline & TAL & 926 & & & & & & & $100 \%$ \\
\hline
\end{tabular}

In the Table 3 obtained from 926 respondents who come from high school education level has filled in the questionnaire and processed using SPSS program. Then the result is as follows: Mean 24.72, Mode 25, Median 25, Minimum Score 8, Maximum Score 39 and Standard Deviation of 4.81. From the results of Table 3 above, obtained from the questionnaire data 926 respondents who came from high school education and above that have been processed in SPSS program, which is more focused on the indicator of Interest Increase Physics Learning Time. The result was that the dominant respondents chose the Good Enough category which was 57.9\% with a total of 536 out of 926 students, Good 22\% with a total of 204 of 926 students, Very Good 3.9\% with a total of 36 of 926 students, Not good 14.3\% with a total of 132 of 926 students, and the least Very Not Good is $1.9 \%$ with a total of 18 of 926 students.

\section{Interest in Career in Physics}

The results of the questionnaire that has been processed about the indicators of Interest in Care in the Field Physics can be seen in Table 4.

In the Table 4 obtained from 926 respondents from high school level have filled in the questionnaire and processed using SPSS program. Then the result is as follows: Mean 32.06, Mode 32, Median 30, Minimum Score 10, Maximum Score 50 and Standard Deviation of 5.69. From the results of Table 4, obtained from the questionnaire data 926 respondents who come from high school education level that has been processed in SPSS program, which is more focused on the indicator Interest Increase Physics Learning Time. The dominant result is that you chose the 45\% Good enough category with a total of 604 out of 926 students, Not Good 26\% with a total of 146 of 926, Good 16\% with a total of 141 of 926 students, Very 
Good 9\% with a total of 11 of 926 students and Very Not Good 4\% with a total of 11 of 926 students.

Table 4. Interest in career in physics at State Senior High School of Batanghari District.

\begin{tabular}{|c|c|c|c|c|c|c|c|c|c|}
\hline \multicolumn{3}{|c|}{ Classification } & \multirow{2}{*}{$\begin{array}{l}\text { Standard } \\
\text { deviation }\end{array}$} & \multirow[t]{2}{*}{ Mean } & \multirow[t]{2}{*}{ Mode } & \multirow[t]{2}{*}{ Median } & \multirow[t]{2}{*}{ Min } & \multirow[t]{2}{*}{$\operatorname{Max}$} & \multirow[t]{2}{*}{$\%$} \\
\hline Range & Attitude & Total & & & & & & & \\
\hline $10-17$ & $\begin{array}{ll}\text { Very } & \text { Not } \\
\text { Good } & \end{array}$ & 11 & & & & & & & $4 \%$ \\
\hline $18-25$ & Not Good & 146 & & & & & & & $26 \%$ \\
\hline $26-33$ & Self & 604 & 5.69 & 32.06 & 32 & 30 & 10 & 55 & $45 \%$ \\
\hline $34-41$ & Good & 141 & & & & & & & $16 \%$ \\
\hline $42-50$ & Very Good & 24 & & & & & & & $9 \%$ \\
\hline & TOTAL & 926 & & & & & & & $100 \%$ \\
\hline
\end{tabular}

\section{Problems in Improving Attitudes}

Table 5. Obstacles encountered in students State High School District Batanghari.

\begin{tabular}{lc}
\hline \multicolumn{1}{c}{ Statement } & Students $(\mathrm{n}=926)$ \\
\hline Adoption Of Scientific Attitudes & 6 \\
& $(0.6 \%)$ \\
Pleasure In Learning Physics & 177 \\
& $(19.1 \%)$ \\
Interest Increases Physical & 27 \\
Learning Time & $(2.9 \%)$ \\
Interest in Career in Physic & 157 \\
& $(35 \%)$ \\
\hline
\end{tabular}

From the results obtained from the respondents who have filled in the questionnaire distributed by the researchers, the researchers found there are 4 obstacles found by students on their attitudes toward the learning of physics (Table 5): Adoption of Scientific Attitude (0.6\%) with a total of 6 of 926 students, Pleasure in Physics Learning (19.1\%) with a total of 177 of 926 students, Interest Increases Physics Learning Time (2.9\%) with a total of 27 of 926, Interest in Career in Physics (35\%) with a total of 157 of 926.

\subsection{Discussions}

In learning, students learn to have an unfavorable learning interest, with the reasons should be a lot of remembering, if they have a high learning interest then it will produce a positive attitude to the subject of physics. Yara (2009) "attitude towards science or physical that shows interest or feeling to science, where the feeling is disposed student to be honest or do not like". Positive attitudes of students from the Learning Group can improve the learning outcomes. Arsaythamby (2015) "The positive attitude of students to Physics has a positive relationship with student achievement." Therefore it is necessary to do learning with students in physics learning. The results of categorization that have been done there are 4 (four) indicators of student attitudes that must be improved in the learning of physics that is the adoption of the scientific attitude, learning physics, interest in increasing the time study of physics, and interest in the field of physics career.

\section{Adoption of a Scientific Attitude}

Based on the results of questionnaire data processing at Batanghari District High School on the most influential attitude indicators categorized well with a percentage of $56 \%$. So it can be generally accepted that the attitude of students in Batanghari High School is quite positive. Results of interviews on students who are categorized good attitude. Students in a classroom environment. The difference is in the discussion if there are some problems that can be accessed with some solutions for the 
students not only in one solution only. This can be seen from below

Question: do you know the problem that occurred in class? If yes why!

Answer: yes I like .. because many references will bring my insight to know how to solve the problem or find a solution to the problem. With many values to be used, there will be a problem that allows us to resolve this issue.

The result of the interview shows that students who have the good attitude toward scientific attitude can think objectively. Olasehinde (2014) "Scientific attitude is the ability to be consistent, rational and objective in solving problems". And the desire of students to solve problems that occur students in the learning process can improve scientific attitudes. Osborne et al (2003) "A good scientific attitude will help students improve good science learning outcomes. Olasehinde (2014) "the better the students' scientific attitude the better the attitude toward science".

\section{Pleasure in Learning Physics}

Based on the analysis of questionnaire data processing at Batanghari High School in the indicator of pleasure in learning physics, the most dominant attitude is the attitude that is categorized enough with the percentage of $55.5 \%$. From the results of these data can be said that the student's pleasure in learning physics enough or average to be positive. The results of interviews on students who categorized the attitude enough known that like to study physics with a variety of reasons for example because the material physics has to do with everyday life and because the learning physics is very nice. This can be seen from the interview shown below:

Question: Do you enjoy studying physics? What is the reason!

Answer: yes happy to learn physics material many advantages in everyday life and comfortable classroom make me better understand the subject of physics, therefore, I enjoy learning physics.

A good attitude toward pleasure in learning physics is an important element in physics learning. Ainley (2011) "states that good physics learning outcomes are influenced by the enjoyment of students' science and pleasure that provide a predictive effect in science learning". One of the positive attitudes of students in the physics learning pleasure indicator is caused by the classroom. Rawatee Maharaj-Sharma (2017) "comfortable classrooms can develop student skills and enhance physics learning pleasure". Pleasure in learning physics that students have will make students enjoy the process of physics learning in the class so that students succeed in learning physics. Lucardie (2014) "that experiencing positive emotions such as fun and enjoyment link with successful learning and self-perception of increased well-being”.

\section{Interest in Increasing Physics Learning Time}

From the results of questionnaire data processing on the indicator of interest in increasing the time of physics study at Batanghari High School showed the dominant attitude of the students are categorized enough that $57 \%$ censored. The category of student attitudes on these indicators proves that only some students are interested in expanding time in physics learning. Based on the results of interviews on students who categorized the attitude well known that when they have finished school they study physics at home individually or in groups and ask friends about the material that has not been understood. This can be seen from the interview shown below:

Question: When you come home from school, do you review the physical materials at home?

Answer: yes, but only occasionally when I feel the material needs to be review.

Question: then is there any material that is not understood in school how?

Answer: yes there is, if I do not understand the material in school then I will go to the library and ask the teacher or friends during break time or when there is an empty hour.

The pleasure of students in learning physics will affect students to increase the time of physics learning. Iksan, et.al (2007) "Interest in spending time in physics students is an important attitude because the interest or interest in physics can make stu- 
dents serious to study physics. Lin (2012) "Students' interest in science subjects, therefore, may be critical in predicting their long-term persistence in science learning". High positive attitudes toward interest in increasing the study of physics will affect learning outcomes. Rodger Bybee (2009) "Students who are interested in increasing the time of physics learning will affect the achievement, the result of learning in physics".

\section{Interest in Career in Physics}

Can be seen from the results of data processing questionnaires at Batanghari High School in the indicator of career interest in the field of physics attitudes of the most dominant students categorized enough that percentage by $46 \%$. The results of these data show the average student has a positive attitude in a career in the field of physics. Based on the results of interviews of students who categorized the attitude is well known that when they mature want to work in the field of physics. This can be seen from the interview shown below:

Question: Are you interested in a career in physics?

Answer: yes, I want a career in physics but not to be a teacher because being a teacher is a tough job.

Interest and interest are the keys to improving students for a career in physics. Arslan (2015) "to be able to improve students in a career in the field of physics to note the interest in which interest greatly affects the achievement of his career and personal life". Juan (2016) "Students' interest in middle school affects science-related careers in the future". In addition to interest, having a positive attitude of students who in physics learning also affects the career of students in the field of physics. Welch (2010) "Having a positive attitude and interest in physics can create an interest in the future career in the field of physics will increase". The attractiveness of a career in the field of physics is one of the good capital to improve the results of physics learning. Rodger Bybee (2009) "Career in physics causes students interested in learning physics that will affect achievement and learning outcomes". Students who want a career in physics will add insight and curiosity to physics.

From the results that have been obtained by the researcher based on the questionnaire that has been disseminated, it is found that the most dominant obstacle, namely Interest in Care in the Field of Physics which has a very high percentage of 926 high school students Batanghari district state, which amounted to 35\%. From the results that researchers found in the field, why the interest of career in the field of physics is very large, it because of lack of interest possessed by each student to deepen the learning physics itself. Because a career in physics must be considered also the interest of students to the lesson itself because interest greatly affects the achievement of career and personal life of students (Arslan, 2015). Then the high constraint percentage level of 926 students is the Pleasure in Learning physics that is $19.1 \%$. From the results that researchers have found, that is why the pleasure in learning physics is quite a high percentage, due to the learning process and less good learning and also the lack of support from facilities and infrastructure which in this case is the condition of the classroom is quite less feasible, resulting in less the pleasure of students studying especially on the subject of physics. Because, a comfortable and decent classroom can develop and cultivate students 'skills and students' enjoyment of learning, especially in physics (Rawate Maharaj-Sharma, 2017).

In the results obtained from the respondents, researchers also found other obstacles, namely Interest Increase Physical Learning Time which has a percentage of $2.9 \%$ of 926 students of Senior High School State Batanghari District. Lack of student interest to multiple learning time, especially studies physics, due to less pleasure of students to the subjects, in this case, will have an effect on student achievement. Students who are very interested to increase their learning time, let alone in learning physics will improve the achievement, learning outcomes and interest in physics career (Rodger Bybee, 2009). Therefore, due to less interested students for a career in the field of physics and lack of fun in learning physics that causes students do not want to multiply the time of physics learning. Furthermore, the researchers also found obstacles experienced by 926 students of State Senior High School of Batanghari District which is a very small percentage, namely the adoption of a scientific attitude of $0.6 \%$. Due to students being scientifical, it will help to get good results, especially in physics lessons (Fakhrudin, 2010). With 
the existence of students who are scientifical, this is what causes the small constraints obtained on the Adoption of the Scientific Attitude.

\section{Conclusions}

From the results of the analysis that has been done, it is found that the attitude of students in high school district Batanghari on the indicators of pleasure in learning physics, interest in increasing the time of physics and career interest in the field of physics students be quite well balanced with the attitude of students on the indicator adoption of scientific attitude students are being nice. This is because sufficient attitudes on these three indicators will affect a good scientific attitude. Attitude enough students is a balanced attitude in the learning of physics because subjects are difficult to understand.

\section{References}

Ainley, M. A. (2011). A Cultural Perspective on the Structure of Student Interest in Science. International Journal of Science Education, 51-71.

Arsaythamby Veloo, R. N. (2015). Attitude towards Physics and Additional Mathematics Achievement towards Physics Achievement. International Education Studies, 35-43.

Arslan, N. I. (2015). High school Students' Educational and Career Interest (Science-Technology-Mathematics) and Career Adaptabilities. Australian Council for Educational Research, 166-172.

Cohen, L. M. (2007). Research Methods in Education. . New York: Routledge.

Creswell, J. W. (2012). Research Design Pendekatan Kualitatif, Kuantitaif dan Mixed Cetakan ke-2. Yogyakarta: Pusaka Belajar.

Darmawangsario, R. (2018). Pengembangan Instrument Sikap Siswa Sekolah Menengah Atas Terhadap Mata Pelajaran Fisika. JPF: Jurnal Pendidikan Fisika, 6(1), 107-114.

Erdemir, N. (2009). Determining Students' Attitude towards Physics through Problem-Solving Strategy. Asia-Pacific Forum on Science Learning and Teaching, 1-19.

Esther Agunbiade, K. N. (2017). An Exploratory Study of the Relationship between Learners' Attitudes Towards Learning Science and Characteristics of an Afterschool Science Club. African Journal of Research in Mathematics, Science and Technology Education, $271-281$.

Fakhrudin, E. E. (2010). Student's Scientific Attitudes in Physics Learning Using the Use of Computer Media through a Model Co-operative Model Type STAD on Students of Class X3 Secondary School in Bangkinang Barat. Jurnal Geliga Sains, 1-22.

Farooq, A. I. (2012). Measurement of Scientific Attitude of Secondary School Students in Pakista. Academic Research International, 379-392.

Giancoli, D. C. (2014). Fisika: Prinsip dan Aplikasi Edisi ke 7 Jilid 1. Jakarta: Erlangga.

Guido, R. M. (2013). Attitude and Motivation towards Learning Physics. International Journal of Engineering Research \& Technology, 2087-2094.

Indonesia, N. 2. 2003. About National Education System. Jakarta : Sinar Grafika

Iksan, Z. H. (2007). Sikap Terhadap Sains dalam Kalangan Pelajar Sains di Peringkat Menengah dan Matrikulasi. Pertanika Journal of Social Sciences \& Humanities, 131-147.

Juan, A. R. (2016). Does It Matter Whether Students Enjoy Learning Science? Exploring Student Attitudes towards Science in South Africa. Human Sciences Reseach Council, 1-6.

Kaya, H. (2011). Attitude towards Physics Lessons and Physical Experiments of the High School Students. European Journal of Physics Education, 23-31.

Kerlinger, F. N. (2014). Foundations of Behavioural Research. Yogyakarta: Gadjah Mada University Press.

Khan, A., Shah, A., \& Mahmood Zareen, R. (2012). Scientific Attitude Development at Secondary School Level: A comparison between methods of teaching language. Review in India, 439-445.

Khine, M. S. (2015). Attitude Measurements in Science Education Classic and Contemporary Appproaches. USA: Information Age Publishing Inc.

Lin, H.-s. F.-F.-R. (2012). Relationships among Affective Factors and Preferred Engagement in Science-Related Activities. Understanding of Science, 941-954.

Lucardie, D. (2014). The Impact of Fun and Enjoyment on Adult's Learning. Procedia-Social and Behavioral Sciences, $439-446$. 
Manasi, L. (2015). Enjoyment of Learning in Upper Secondary Education. An exploratory research. Procedia-Social and Behavioral Sciences, 639-646.

Olasehinde, K. J. (2014). Scientific Attitude, Attitude to Science and Science Achievement of Senior Secondary School Students in Katsina State, Nigeria. Journal of Educational and Social Research, 445-452.

Olasimbo, O. A. (2012). Attitudes of Students towards the Study of Physics in College of Education Ikere Ekiti, Ekiti State, Nigeria. American International Journal of Contemporary Research, 86-89.

Rawatee Maharaj-Sharma, A. S. (2017). Using Ict in Secondary School Science Teaching-What Students and Teachers in Trinidad and Tobago Say. European Journal of Education Studies, 197-211.

Rodger Bybee, B. M. (2009). PISA 2006: An Assessment of Scientific Literacy . Journal of Research in Science Teaching, 865-883.

Saleh, S. (2014). Malaysian Students' Motivation towards Physics Learning . European Journal of Science and Mathematics Education, 223-232.

Visser, Y. L. (2007). Convergence and Divergence in Children's Attitudes toward the Sciences and Science Education. Florida Atlantic University: Learning Development Institute.

Welch, A. G. (2010). Using the TOSRA to Assess High School Students' Attitudes toward Science after Competing In the FIRST Robotics Competition: An Exploratory Stud. Eurasia Journal of Mathematics, Science \& Technology Education, 187-197.

Wood, K. (2011). Education is Basic. New York: Taylor \& Francis Group.

Yara, P. (2009). Relationship between Teacher's Attitude and Students' Academic Achievement in Mathematics in Some Selected Senior Secondary Schools in South-Western Nigeria. European Journal of Social Sciences, 364-369. 